\title{
A Test of the Possible Reduction of the Digging Activity of Moles in Pastures by Increasing Soil Nitrogen
}

MOŻLIWOSCI OGRANICZENIA KOPIACEJ DZIAEALNOSCI KRETA NA PASTWISKAGH PRZEZ NAWOZENIE AZOTEM

\section{H. SCHAEFER}

Schaefer V. H., 1981: A test of the possible reduction of the digging activity of moles in pastures by increasing soil nitrogen. Acta theriol., 26, 7: 118-123 [With 2 Tabies].

The level of nitrogen fertilizer (140 kg N/ha) was found in this study to reduce soil $\mathrm{pH}$ and the weights of earthworms (Lumbricus rubellus) in the laboratory. Nitrogen fertilizer (70 kg N/ha; $140 \mathrm{~kg} \mathrm{~N} / \mathrm{ha}$ ), was applied to pastures in an attempt to reduce the densities of molehills of the Coast Mole (Scapanus orarius) in British Columbia. No reduction in molehill densities occurred with the fertilizer treatments, possibly because soil and weather conditions interfered with the acidifying ability of the fertilizer.

[Dept. Biol. Douglas College, P.O. Box 2503, New Westminster, B.C. V3L 5B2 Canada]

\section{INTRODUCTION}

Ennik (1967) reported that ammonium nitrate limestone reduced the number of molehills produced by the European Mole (Talpa europaea) in pastures. He reported that the number of molehills decreased somewhat when a pasture was cut, decreased more if the pasture was grazed continuously by cattle, decreased even more under conditions of rotational grazing with low nitrogen application $(70 \mathrm{~kg} \mathrm{~N} / \mathrm{ha})$, and decreased the most when rotationally grazed with high nitrogen application (140 kg N/ha).

Ennik concluded that nitrogen fertilizer was effective in reducing molehill densities, which suggests its use for mole control. Moles can cause considerable economic damage (Wick, 1961), and there is no single economic or desirable method for effectively controlling moles. The three most efficacious methods known at present are: the English scissor trap, poison baits (Kuhn, 1970; Glendenning, 1959), and pesticides (Shilova et al., 1971). The latter kill earthworms, the major food source of several mole species. This method is, then, undesirable because farthworms also enhance soil fertility (Guild, 1948).

The purpose of this study was to first determine a possible mechanism for a reduction in molehill numbers by nitrogen fertilizer. One probable change in an edaphic environment brought about by an application of nitrogen fertilizer is to make the soil more acidic. Earlier work (Schaefer \& Sadleir, in press), determined that molehill densities were indeed related to soil $\mathrm{pH}$. Thus, in the first part of this study, laboratory experiments were conducted to determine if soil $\mathrm{pH}$ was reduced by the levels of nitrogen fertilizer used by Ennik in his pastures. Also, any alterations of earthworm weights due to changes in soil $\mathrm{pH}$ were measured; it was postulated that soil $\mathrm{pH}$ affects the digging activity of a mole only indirectly by reducing the amount of its available food supply, which is chiefly earthworms. 
The second part of the study was to try to duplicate Ennik's field experiment using the same amounts of nitrogen additions to pastures, but using a somewhat different experimental design. Any changes in molehill densities were noted.

\section{METHODS}

\subsection{The Effect of Nitrogen Fertilizer on Soil pH and Earthworm Weights}

Ten one-gallon (4.5 1), square jars were filled with alternating layers of fine aquarium gravel and potting soil with dolomite. A layer of $500 \mathrm{mls}$ of gravel was placed into the bottom of each jar, folowed by $500 \mathrm{mls}$ of potting soil which was ligithtly pressed. These were followed by $250 \mathrm{mls}$ of gravel, $500 \mathrm{mls}$ soil, $250 \mathrm{mls}$ gravel, and $500 \mathrm{mls}$ soil.

Five of the jars were used as controls. The remaining five received an amount of Terico fertilizer $34-0-0$ (nitrogen as nitrate and ammonia) equivalent to $140 \mathrm{~kg} \mathrm{~N} / \mathrm{ha}$. Thus, $0.92 \mathrm{gm}$ of fertilizer was uniformly spread over the soil in each of five jars. A layer of $500 \mathrm{mls}$ of crumbled leaf litter collected in an alder thicket was then added to each of the 10 jars as a food supply for the earthworms, and then each received $500 \mathrm{mls}$ of tap water poured $100 \mathrm{mls}$ at a time over the litter.

Earthworms (Lumbricus rubellus) were individually washed, dried with a paper towel, weighed, and then placed in a random manner six in each jar, except due to an error one experimental jar received seven earthworms, and one control jar received only five. The jars were covered with paper towels sealed with rubber bands, and then completely wrapped in black plastic which prevented light exposure. They were kept in a room at $12-14^{\circ} \mathrm{C}$ for 40 days. After this period, the earthworms were removed, washed, dried with paper towels, and weighed. Also, soil samples were taken from each of the three layers of potting soil of the 10 jars, and allowed to air-dry; soil sample weights were measured before and after drying. Soil $\mathrm{pH}$ was determined by mixing equal quantities of the dried soil and water, and reading the soil $\mathrm{pH}$ from a digital $\mathrm{pH}$ meter (McMullan, 1972).

\subsection{The Effect of Nitrogen Fertilizer on Molehill Numbers in Pastures}

Fifteen territories of the Coast Mole (Scapanus orarius) were located in pastures on a dairy farm near Maple Ridge, British Columbia. Single territories were delineated by looking for discrete areas of mole activity and then marking them as rectangles about $30 \times 40 \mathrm{~m}$, the approximate territory size of this species and moles in general (Godfrey \& Crowcroft, 1960; Schaefer, 1979). All molehills were iritially counted for each territory, and then only new hills at subsequeunt counts. Of the 15 territories, 5 were randomly assigned as controls, 5 to receive $70 \mathrm{~kg} \mathrm{~N} / \mathrm{ha}$, and 5 to receive $140 \mathrm{~kg} \mathrm{~N} / \mathrm{ha}$.

On 25 April, 1978, the complete amount of nitrogen ( 70 or $140 \mathrm{~kg} \mathrm{~N} / \mathrm{ha}$ ) was apolied to the appropriate plots as Scotts 41-0-0 (the nitrogen was $75 \%$ water souble, $25 \%$ water insoluble from urea). Ennik had applied this full amount of nitrogen as ammonium nitrate in two equal treatments.

In a second application on 11 July, the appropriate plots were again treated with nitrogen, with the addition of phosphorus and potassium at the same levels used by Ennik (1965) in one of his treatments. The forms of phosphorus $\left(\mathrm{P}_{2} \mathrm{O}_{2}\right)$ and potassium $\left(\mathrm{K}_{2} \mathrm{O}\right)$ were the same as used by Ennik, as were the rates of application which were about $9 \mathrm{~kg} / \mathrm{ha}$ each. One-quarter of the nitrogen was applied in the form of nitrate, and one-quarter as ammonia using the fertilizer Terico $34-0-0$. The other half of the nitrogen was applied as urea in Green Valley 16-16-16. All fertilizer was applied using a rotary hand spreader.

The number of new molehills in each of the 15 territories was counted at approximately two-week intervals. Soil samples were collected from three territories only - a control, one with $70 \mathrm{~kg} \mathrm{~N} / \mathrm{ha}$, and one with $140 \mathrm{~kg} \mathrm{~N} / \mathrm{ha}$ added. Fiye soil samples were collected from each of these three territories on the days of the hill counts. Soil samples were collected from a depth of $10 \mathrm{~cm}$. Of the 
five samples from each territory, four were collected one $\mathrm{m}$ in from each corner of a territory, and the fifth was collected from its center. Soil moisture contents were calculated. Then a sample of the dried soil was ground and passed through a 24 mesh sieve. The $\mathrm{pH}$ of the soil was then determined on a 10 cc subsample of this ground soil.

\section{RESULTS}

\subsection{The Effect of Nitrogen Fertilizer on Soil pH and Earthworm Weights}

The $\mathrm{pH}$ of the soil in the control jars after the experiment was $5.90 \pm 0.12$, and the experimental group $5.61 \pm 0.10$. An analysis of variance showed that the difference in $\mathrm{pH}$ between the groups was significant $(F=12.2 ; p \leqslant .01)$. In each case the sample size was 15 ( 5 jars in each of the two conditions, 3 samples per jar).

The fertilizer was found to significantly reduce the weights of earthworms. The earthworms in the fertilizer-treated group declined in average weight from $3.58 \pm 0.38 \mathrm{gm}(\mathrm{N}=31)$ to $3.20 \pm 0.29 \mathrm{gm}(\mathrm{N}=30$; one death). The weights of the control group increased in average from $3.68 \pm 0.38 \mathrm{gm}$ to $3.79 \pm 0.35 \mathrm{gm} \quad(\mathrm{N}=29)$. The difference in weight between the fertilizer-treated and control groups after the experiment was significant $(F=7.2 ; p \leqslant .01)$. Before the experiment the difference in weights between the fertilizer-treated and control groups was not significant $(F=0.13 ; p=0.72)$.

\subsection{The Efiect of Nitrogen Fertilizer on Molehill Numbers in Pastures}

Table 1 summarizes the number of molehills found at each sampling date for the control, $70 \mathrm{~kg} \mathrm{~N} / \mathrm{ha}$ treated, and $140 \mathrm{~kg} \mathrm{~N} /$ ha treated ter-

\section{Table 1}

Seasonal changes in the number of molehills for the combined territories (five in each group) in each treatment.

\begin{tabular}{rrrr}
\hline \multicolumn{1}{c}{ Date } & Control & $70 \mathrm{~kg} \mathrm{~N} / \mathrm{ha}$ & $140 \mathrm{~kg} \mathrm{~N} / \mathrm{ha}$ \\
\hline 25 April (pretreatment) & 139 & 229 & 173 \\
4 May & 99 & 130 & 177 \\
16 May & 165 & 229 & 145 \\
1 June & 104 & 225 & 163 \\
2 June & 52 & 142 & 105 \\
4 July & 86 & 138 & 99 \\
18 July & 68 & 151 & 84 \\
1 August & 23 & 90 & 20 \\
15 August & 3 & 5 & 119 \\
2 August & 40 & 105 & \\
\hline
\end{tabular}

ritories. There were no apparent reductions in the number of molehills due to the fertilizer treatments.

Table 2 presents the numbers of molehills, soil $\mathrm{pH}$, and soil moisture for the three mole territories used in taking soil measurements. There swas no reduction in the $\mathrm{pH}$ of the soil as a result of the fertilizer treatments. When data from the three plots were combined $(\mathrm{N}=30)$, 
only the correlations between the number of molehills and soil $\mathrm{pH}$ $(\mathrm{r}=0.69 ; p \leqslant .01)$, and the number of molehills with soil moisture $(r=0.40$; $p \leqslant .05$ ), were significant.

There were levels of $2-25 \mathrm{ppm}$ nitrate nitrogen, and $1-2 \mathrm{ppm}$ ammonia, in some of the fertilizer-treated plots after the second fertilizer application. These levels were present in the soil until the end of the study. This indicated that nitrogen from the fertilizer had entered into the soil for a dedth of at least $10 \mathrm{~cm}$. There was less than one ppm nitrate nitrogen and ammonia in the untreated control plot.

Table 2

The number of molehills (A), soil $\mathrm{pH}(\mathrm{B})$, and soil moisture content in percentage (C) of three mole territories.

One territory was a control in the field experiment, one received $70 \mathrm{~kg} \mathrm{~N} / \mathrm{ha}$, and one $140 \mathrm{~kg} \mathrm{~N} / \mathrm{ha}$.

\begin{tabular}{|c|c|c|c|c|c|c|c|c|c|c|}
\hline \multirow{2}{*}{\multicolumn{2}{|c|}{ Date }} & \multicolumn{3}{|c|}{ Control } & \multicolumn{3}{|c|}{$70 \mathrm{~kg} \mathrm{~N} / \mathrm{ha}$} & \multicolumn{3}{|c|}{$140 \mathrm{~kg} \mathrm{~N} / \mathrm{ha}$} \\
\hline & & A & B & C & A & B & $\mathrm{C}$ & A & B & $\mathrm{C}$ \\
\hline & April & 38 & 4.66 & 41.5 & 58 & 4.82 & 31.8 & 75 & 4.66 & 42.7 \\
\hline 4 & May & 35 & 4.55 & 43.5 & 39 & 4.77 & 36.0 & 41 & 4.77 & 47.1 \\
\hline 16 & May & 65 & 4.69 & 38.1 & 76 & 5.05 & 34.3 & 37 & 4.85 & 41.6 \\
\hline 1 & June & 31 & 4.62 & 45.1 & 69 & 4.94 & 40.8 & 39 & 4.70 & 49.0 \\
\hline 20 & June & 22 & 4.56 & 21.6 & 54 & 4.91 & 19.2 & 14 & 4.56 & 25,4 \\
\hline 4 & July & 19 & 4.61 . & 29.6 & 80 & 5.20 & 27.6 & 46 & 4.81 & 38.9 \\
\hline 18 & July & 32 & 4.41 & 23.0 & 77 & 4.88 & 24.5 & 41 & 4.60 & 32.7 \\
\hline 1 & August & 11 & 4.67 & 20.9 & 43 & 4.88 & 18.5 & 34 & 4.76 & 24.7 \\
\hline 15 & August & 2 & 4.44 & 14.9 & 1 & 4.79 & 11.9 & 6 & 4.44 & 16.5 \\
\hline 29 & August & 33 & 4.63 & 25.0 & 49 & 4.85 & 19.2 & 51 & 4.69 & 31.6 \\
\hline
\end{tabular}

\section{DISCUSSION}

Nitrogen fertilizer in treatment of $70 \mathrm{~kg} \mathrm{~N} / \mathrm{ha}$ and $140 \mathrm{~kg} \mathrm{~N} / \mathrm{ha}$ did not reduce molehill densities. Before treatment with fertilizer those plots used in the $70 \mathrm{~kg} \mathrm{~N} / \mathrm{ha}$ treatment had the greatest combined number of molehills and the control plots the least. This relationship was generally maintained for four months after the fertilizer was first applied. Even the second application of fertilizer, which had the nitrogen in the same form as used by Ennik, plus the same forms and amounts of phosphorus and potassium, had not affect on molehill densities.

In the laboratory, nitrogen fertilizer at a rate equivalent to $140 \mathrm{~kg}$ $\mathbb{N} /$ ha significantly did reduce the $\mathrm{pH}$ of the soil, and the weight of earthworms in the soil, The reductions are small, and may not the biologically significant in themselves, but they do illustrate the expected trend of a reduction of soil $\mathrm{pH}$ by nitrogen fertilizer. They also illustrate that the weights of earthworms would be reduced. Reductions in earthworm weights by other acidifying fertilizers have been demonstrated by many other researchers (e.g., Jefferson, 1955). In another paper (Schaefer \& Sadleir, in press), it was demonstrated that molehill densities are significantly positively correlated with earthworm weights (perhaps because moles dig more when they have more available energy), and with soil $\mathrm{pH}$, as in the present study, probably because of its effect 
on earthworms (Satchell, 1955). The significant correlation between soil moisture and molehill numbers may indicate that moles dig more when it is easier for them to dig. The ground would be easier to dig in if the soil moisture content was high, and more difficult when it was dry and hard. Alternatively, soil moisture may influence earthworm weights or earthworm activity in some way.

In the field experiment the nitrogen fertilizer did not reduce soil $\mathrm{pH}$ as would be expected from the reaction of ammonia with water producing ammonium hydroxide and free hydrogen ions. The ability of nitrogen fertilizer to reduce soil $\mathrm{pH}$ depends on a variety of factors. These include the nature of the micelle, the base saturation of the soil, the ratio of the cations in the soil, and weather, particularly rainfall (Buckman \& Brady, 1969). The field chosen for this experiment was high in calcium (ca. $450 \mathrm{ppm}$ ), and, as is reflected in the soil moisture information presented, rainfall was low. Both these factors would contribute to an inability of the nitrogen fertilizer to reduce soil $\mathrm{pH}$ and hence earthworm weights.

Ennik (1967) had applied limestone with ammonium nitrate on his plots with the nitrogen fertilizer, perhaps in an attempt to counter the acidifying nature of the ammonium nitrate. However, he may not have significantly countered this trend (Buckman \& Brady, 1969). He may have reduced soil $\mathrm{pH}$ in his plots (he mentions no soil $\mathrm{pH}$ data in his results), and hence molehill densities.

Alternatively, unless there is a species difference between the European and Coast moles in response to the fertilizer, it may in fact be that the nitrogen fertilizer in Ennik's experiments had no effect on molehill densities. Although inspection of Ennik's (1967) data indicates that the areas of high nitrogen fertilizer application had consistently low numbers of molehills, the absence of pretreatment data precludes the interpretation that high amounts of nitrogen necessarily reduce molehill numbers.

The use of an acidifying fertilizer in controlling molehill activity is very desirable in terms of its ease of application and low cost. However, the main property of the fertilizer which may control molehill numbers may well be the reduction in soil $\mathrm{pH}$. This would make the fertilizer less attractive as a form of mole control because the increased soil acidity would be detrimental to pastures and crops.

Acknowledgements: I would like to thank Dr. R. M. Sadleir for his supervision and encouragement. This research was funded by an NRC grant to Dr. Saddleir.

\section{REFERENCES}

Buckman H. O. \& Brady N. C., 1969: The nature and properties of soils. Collier MacMillan Ltd: 1-653. London, 7th Ed. - Ennik G. C., 1965: The influence of management and nitrogen application on the botanical composition of grassland. Neth. J. Agr. Sci., 15: 221-228. - Ennik G. C., 1967: Mole activity in relation to pasture management and nitrogen fertilization. Neth, J. Agr. Sci., 13: 222-237. - Glendenning R., 1959: Biology and control of the coast mole, Srapanus orarius, in British Columbia. Can. J. Anim. Sci., 39: 34-44-Godfrey G. K. \& Crowcroft P., 1960: The life of the mole. Museum Press: 1-163: London. - Guild E. J. McL., 1948: Studies in the relationship between earthworms and soil fertility. III. The effect of soil type on the structure of earthworm populations. Ann. Appl. Biol., 25: 181-193. - Jefferson P., 1955: Studies on the earthworms of turf. A. The earthworms of experimental turf plots. J. Sports Turf Res, Inst., 9: 6-27. - 
Kuhn L. W., 1970: Mole control. [In: Proceedings 4th Vertebrate Pest Conference. Dana R. H. ed.], 71-76. West Sacramento, Calif. - McMullan E. E., 1972: Methods of analysis. Part 2. Soils. Biochem. Lab. Serv. Can. Forest. Serv. Bull. No. BC-X-67. Victoria, B. C. - Satchell J. E., 1955: Some aspects of earthworm ecology. [In: Soil Zoology. Kevan D. K. McE. Ed.]. Butterworths, 180-201. London: - Schaefer V. H., 1979: Aspects of habitat selection in the coast mole (Scapanus orarius True) in British Columbia. Simon Fraser University Ph. D. Thesis. 205 pp. Schaefer V H. \& Sadleir R. M. Factors influencing molehill densities in pastures. Mammalia (in press). - Shilova S. A., Denisova A. V., Dmitriev C. A., Voronova L. D. \& Bardier M. N., 1971: Effect of some insecticides upon the common mole. Zool. Ž., 50: 886-892 [In Russian]. Wick W. A., 1961: Mole control takes some doing. Oreg. Farm. 84: 5-6.

Accepted, September 25, 1980.

\title{
Verification of Censusing Techniques for the Wyoming Ground Squirrel
}

\author{
OCENA METOD WYEOWU SPERMOPHILUS ELEGANS
}

\section{David A. ZEGERS ${ }^{1}$}

Zegers D. A., 1981: Verification of censusing techniques for the Wyoming ground squirrel. Acta theriol., 26, 7: 123-125 [With 1 Fig.]

Direct counts and the minimum number known to be alive derived from capture-mark-release data gave essentially the same density estimates for a montane population of Wyoming ground squirrels, Spermophilus elegans.

[Dept. Environment., Population and Organismic Biol., Univ. Colorado, Boulder, CO. 80309, USA]

Verification of the accuracy of censusing techniques is an important but ofter neglected research activity. Basically, accuracy can be assumed 1) when utilizing a technique on a population of known size gives results similar to that known density or 2) when two completely independent census methods produce comparable results (Bergerud, 1968). The objective of this study was to test the precision of censusing techniques for Wyoming ground squirrels, Spermophilus elegans elegans Kennicott, 1863.

During the summer of 1975 , the animals were studied in a montane meadow ( $2440 \mathrm{~m}$ elevation above sea level) on the eastern slope of the Front Range of the Rocky Mountains, approximately $16 \mathrm{~km}$ southwest of Boulder, Colorado, USA (Zegers \& Williams, 1979). The study site of 3.6 ha was located in the center of a gently sloping, bowl-shaped 76-ha horse pasture.

Two censusing techniques were used and compared. The first was a CMR procedure that involved catching the squirrels with National live-traps (\#201) and marking them with ear tags and freeze-brands such that individuals would be recognizable at a distance (Hadow, 1972;

${ }^{1}$ Present address: Dept. Biol., Millersville State Coll., Millersville, Pa. 17551, USA. 